\title{
The Traditional State as a Specific Form of Political Organization
}

\author{
Valentin Ya. Liubashits ${ }^{1}$, Nikolai V. Razuvaev ${ }^{2}$, Natalia V. Fedorova ${ }^{3}$, Georgii Ia. Trigub ${ }^{4}$ \& Oleg V. Soloviev ${ }^{5}$ \\ ${ }^{1}$ Dr. habil. in Law science, Professor, Department of Theory and History of State and Law, Russia \\ ${ }^{2}$ Dr. habil. in Law science, Professor, Head of the Department of Civil and Labor Law, North-West Institute of \\ Management, Russian Academy of National Economy and Public Administration, Russia \\ ${ }^{3} \mathrm{PhD}$ in historical sciences, associate professor, Russia \\ ${ }^{4} \mathrm{PhD}$ in Historical Sciences, Associate Professor Vladivostok State University of Economics and Service, \\ Russia \\ ${ }^{5}$ Lecturer of the Department of Political Science and Ethnopolitics, South Russian Institute of Management \\ (branch) of the Russian Presidential Academy of National Economy and Public Administration, Russia \\ Correspondence:, Valentin Ya. Dr. habil. in Law science, Professor, Department of Theory and History of State \\ and Law, Russia. E-mail: info@ores.su,
}

Received: June 9, 2019

doi:10.5539/jpl.v12n5p96
Accepted: August 25, $2019 \quad$ Online Published: August 31, 2019

URL: https://doi.org/10.5539/jpl.v12n5p96

\begin{abstract}
The article analyzes the traditional state as a historical, political, legal, and cultural phenomenon that has had a fundamental impact on the transformation of the socio-political organization of society, on the legal and socio-cultural development of modern social systems. The authors argue that the traditional state should be characterized as a specific form of the political, legal, social, and cultural organization since it contains all the institutions that provide for the management of various processes in society, and has the operating forms and mechanism of its preservation and reproduction. In addition, the work shows that the traditional state forms special legal regimes, as well as forms of socio-political integrity. The authors prove that the specificity of the traditional state as a historical type has manifested in a whole series of system characteristics (functions, structure, and forms) incomparable in full with the organizational features of other historical types of states, primarily the modern state.
\end{abstract}

Keywords: state, law, institutions, culture, society, evolution

\section{Introduction}

Statehood has been forming among the peoples of the world in different ways. The first page in the history of post-primitive society is a long era of statehood of peoples who lived in the IV millennium BC - I millennium BC in the territory of North-East Africa, Western, South and East Asia, in the Mediterranean basin. The first states arose on the basis of the slave-owning civilizations of the Ancient East - in Egypt, Mesopotamia, Asia Minor, India, and China. The slave-owning state reached its highest development in the ancient era - the heyday of the slave-holding antique statehood on the Balkan Peninsula, on the coast of Asia Minor, on the Aegean Sea, and on the Apennine Peninsula - in Ancient Greece and Ancient Rome.

The first statehood on earth that arose in the Ancient East - Egypt, Babylon - is distinguished by special laws due to the specifics of Egyptian, Babylonian and their other contemporary civilizations [Nersesiants, 1985; Martyshin, 2003; Grafskii, 2003]. The emergence of the state in the Ancient East is characterized by the following main features:

1) The preservation of the basic economic and social structures of the primitive system (the land community and poor development of individual land ownership; the significant role of collective ownership, in particular, collective ownership of slaves, which belonged mainly to the state, temples);

2) The presence of institutions of patriarchal life, and in some countries - even traces of matriarchy;

3) Primitive forms of slavery with the preservation of domestic slavery, where the slave had the opportunity to use and dispose of his property and even start a family.

Thus, the first form of statehood, which formed, in particular, in Egyptian civilization, is characterized by the 
emergence of a state (named in the literature as Eastern despotism) in the absence of private ownership of land and, accordingly, the absence of classes in understanding them as groups of people with different attitudes to fixed assets [Liubashits, et al 2015]. The first states in the Ancient East were pre-class.

\section{Historical Background}

In the evolution of primitive societies, a group of primary and secondary states can be distinguished. Primary states formed in favorable climatic zones as a result of their own independent development.

A.B. Vengerov wrote in particular about the "primary" states in Mesopotamia, Mesoamerica, in Mountainous Peru: "The village (settlement) where free communal farmers live and which has stood out as a religious and economic center from the group of original villages, is gradually growing into an administrative-economic and religious center-city-state. Together with the adjacent small agricultural area, it becomes a city-state. Such a city-state already knows social differentiation, property stratification; the division of labor is territorially fixed; the initial control apparatus is formed. At the same time, three centers of management, administrative and ideological leadership are formed: the urban community, the palace, and the temple, which leads to the creation of an extensive bureaucratic apparatus.

The need to consider the demand of free community farmers - the main social and productive force of the early farming society - for land, water, irrigation facilities, to determine the contribution to public works (the construction of canals, bridges, roads), to create and take into account public funds, tribute, taxes, keep records of reserves, etc. objectively led to the emergence of branched information systems in the first city-states, which documented the most diverse data even about each member of the specific family" [Apolskii, et al 2017].

Thus, the primary states either surpassed in their genesis such fundamental social processes as the formation of institutions of "private" property and class formation, or these processes proceeded in parallel, albeit closely interconnected. A.B. Vengerov writes that "at the very first, embryonic stages of its emergence, the primary state arose simultaneously with the division of society into early class structures - elite, wealthy citizens, free communal farmers, artisans, and dependent persons. The primary apparatus usually consisted of the social structures of the management of the agricultural community but in terms of its functions and attitude towards the community, to adjacent villages, it was already the apparatus of the city-state. The class nature of the primary states is clearly defined only over time, when the stratification of society and class formation led to the seizure of the state apparatus by the ruling class and its adaptation to their interests and needs" [Vengerov, 1983].

Secondary states arose alongside the primary ones and, under the influence of the latter, borrowed certain institutions or structural principles. The neighbors of developed centers often seized and extended their structures to the already existing social stratification, creating a "superstratification" society [Butenko, 1993]. Most often this was observed during the conquest of agricultural civilizations by nomadic cattle herders.

Another historical way of state formation is represented by ancient Athens and Rome. Ancient statehood is characterized by the formation through the successive decomposition of the clan organization of power during the transition from collective to private ownership of land and tools of production. On the territory of Attica (Greece) until the VIII century BC, there was a primitive communal system. The tribes - the philae that inhabited Attica, were governed by such bodies as the tribal leader (basileus), the council of elders, and the national assembly. The division of labor and the development of the monetary economy contribute to the dissolution of patrimonial relations. Free community members lose ground, debt bondage grows. The number of slaves is increasing, including through prisoners of war. Tribal organs are transformed into state organs: the functions of the Basileus are transferred to 9 archons (elders), selected annually from the elite; the tribal council of elders is replaced by an areopagus made up of former archons; national assemblies, although they remain, lose their significance; tribal (ethnic) phyles are replaced with territorial division is introduced; new bodies are established (five hundred council, collegium of strategists), elected by the free population outside of tribal relations. Similar processes of state formation, with well-known specifics, took place in Ancient Rome. As noted in the literature, the emergence of ancient slave states is by no means a universal way of forming statehood but reflects a specific form of statehood formation, characteristic only of ancient Greece and ancient Rome, their unique civilizations. Moreover, the subject of heated debate today is the question of whether the ancient polis is the state. M. Berent believes that the policy was a "stateless society." In his opinion, the Athenian leader neither held any formal posts nor had at his disposal the state coercive apparatus [Berent, 2000]. Only the dictatorship of Sulla, the reign of Pompey, the first triumvirate, the reign of Caesar, Augustus can be attributed to the state, according to the supporter of this position - domestic researcher E.M. Staerman.

Thus, the evolution of social power in a tribal community into state power is far from a one-dimensional structure. The formation of the state is a multilinear, multivariate process. So, the issue of the specific origin of 
statehood among the Eastern Slavs, of the laws of their statehood, has not been sufficiently studied yet. During the dissolution of primitive society, as a rule, an "archaic state" forms, based on the so-called "Asian mode of production" (Ancient East, Africa, America, Oceania). As noted in the literature, "another development option is also possible, which is especially characteristic of Europe: the dissolution of primitive communal formation leads to an ancestral formation, which only then becomes real feudalism" [Zakharov, 1999; Liubashits, 2016].

\section{Overview of Approaches and Research Positions}

The complexity and ambiguity of the concrete historical processes of the formation of the state led to various points of view in science on the explanation of the universal causes of its appearance.

This is quite natural and understandable since each of them reflects either different views and judgments of different groups, layers, classes, nations and other social communities on this process, or the views and judgments of the same social community on various aspects of this process of origin and development of state and law.

The processes of polytogenesis are influenced by both endogenous and exogenous factors. These include an increase in surplus product, new technologies, wars, conquests, and trade [Liubashits, 2002].

The scientific literature provides two main approaches to explaining early statehood. One of them belongs to E. Servis already mentioned above. According to the "integrative" version, the state arises as a result of the transformation of the managerial structures of an increasingly difficult society. There is already a comprehensive economic and social infrastructure. Features include highly developed and specialized craft and trade, large monumental construction, the emergence of cities, writing, and law. According to the second, "conflict" approach by M. Fried, the state as an organization is designed to stabilize relations in a complex stratified society. Conflict explanation of the origin of the state comes from the relations of exploitation, class struggle, war, and interethnic contradictions [Fried, 1967].

Marxist-oriented researchers also join this version. An interesting point in this dispute is the position of N.N. Kradin. He, as we think, is right when he notes that "in reality, both integration and conflict are simultaneously present in the nature of the state" [Kradin, 2001]. Indeed, it (the state) refers to the protection of its inhabitants from external enemies, criminals, carries out organizational functions, and other important social functions. At the same time, the political authorities manage resources and various benefits and thereby create status inequality.

The traditional state in literature is also called "archaic", or "early". In domestic scientific literature, it was called "early class society." In foreign political anthropology, H.J. Klassen actively participated in the development of the theory of the early state. He and his co-author P. Skalnik created the classic work - "The Early State" (1978), which gives a description of the state as follows: it is a centralized sociopolitical organization for regulating social relations in a complex stratified society, divided into two main strata or classes, - managing and managed persons, the first of which exercise political dominance, and the latter have tributary duties [Claessen \&Skalnik 1978].

In the same work, they proposed a typology of early states: "embryonic", "typical", and "transitional". Each of them corresponds to a certain degree of maturity. The "embryonic" state was distinct for the dominance of clan ties and the existence of officials due to the share of redistribution; lack of legal codification and special judicial bodies; insufficient development of the management apparatus. "Typical" state - for maintenance of lineage (groups of single-line relatives) with the transition to an extra-clan control subsystem; the appearance of a fixed code of laws, a special apparatus of judges, special officials. "Transitional" early state is characterized by dominance of appointment to the post in the administrative apparatus, salaries to officials instead of the existing practice of "feeding"; there is a judiciary that solves all issues of lawmaking; functioning tax system; main areas of life are controlled by the bureaucracy [Claessen \&Skalnik 1978].

Modern experts distinguish a different number of criteria testifying to the difference between the state and previous organizations.

S. Nadel used three differentiation criteria: first, territorial sovereignty; second, a centralized management apparatus that protects the law and maintains order; third, the existence of a specialized and privileged ruling group or class, separated by its status and organization from the rest of the population.

Domestic researcher Iu.V. Pavlenko identifies two models of the early states, which differ from each other in the functions performed. One type of early state was called point, and the other - territorial. The point states were city-states (ancient Egyptian and ancient Sumerian "nom states" of the third phase according to I.M. Diakonov). The ancient Sumerian state was divided into two sectors: large farms that fell outside the jurisdiction of 
communal self-government bodies and which (farms) were owned by churches and the top officials. The second sector included lands that belonged more to family communities led by their patriarchs. Redistribution of the product occurred through the cities which had the operating state administration. Exchange both in the domestic and in the external market took place as an exchange of gifts or on the basis of nonequivalent "mutual assistance", that is, in the form of economic redistributive activity.

The territorial early states were large political communities, the center of which was the city-capital, surrounded by economically independent provinces (specific principalities). The surplus labor in such states, in contrast to the first, point state (with its organizational, economic and economic redistributive functions), was withdrawn on the basis of redistributive and tributary exploitation.

\section{Main Part}

If there are different approaches to assessing the criteria and signs of a traditional state, few researchers insist on universal indicators. Nevertheless, usually, three main features of statehood, including its early stages, are distinguished: territorial division, taxes, and the formation of the apparatus of power and administration. We will analyze four main features in a sequence slightly different from the usual one.

The identification of features of the state can be carried out both by analyzing the features which embed its social purpose, a special role in society (the so-called functional signs), and by characterizing the signs which express the specificity of the internal organization of power (the so-called structural features).

Historically, the first feature of an emerging state was the replacement of the tribal organization of the territorial population [Baburin, 1997.]. The latter was due to the fundamentally new nature of the connection between the producing economy, brought to life by the Neolithic revolution, with its natural prerequisites, the intensive development of exchange and localization (during the fragmentation of tribes and peoples) of real estate, land, and buildings as objective prerequisites for social production. As a property and social differences deepened, the territory where production was carried out no longer acted as a prerequisite but as a place of "action" of social labor. This naturally led to the displacement of kinship ties, which hinder the further development of the productive labor force, by production and territorial ties arising from the common economic interests.

$\mathrm{K}$. Marx traces the genesis of the territorial organization of the population in the book by Morgan mainly on the example of Greece and Rome. Unlike ancient Eastern civilizations, the diversity of natural conditions in the Mediterranean contributed to the rapid development of the division of labor, crafts, and exchange. The focus of political life here was the city where the fragments of different clans, tribes, ethnic groups (peoples) came to and mixed together. The stereotypes of collective discussion of the most important cases, characteristic of the tribal community, transferred to the new conditions (of an indirect generalization and a representative form of expression of common will) gave rise to specific structures of the ancient slave-owning democracy of the owners of the means of production. The related role of the city as the epicenter of the emerging political life, the public struggle of opposing interests (and not just opinions), the development of social compromises, etc. have escaped the attention of K. Marx. Outlining Morgan's thought about the long (about three centuries) period during which in Ancient Greece "the transition from a patrimonial organization to a political (civil)" took place, Marx adds in brackets: "He should have said that the term "political" is used here in the Aristotelian sense: political means urban, and political animal means a city dweller".

This remark, in addition to the clarification that is essential for understanding Morgan's view, contains an important thought: the development of the clan organization into the state, as noted above, is not limited to the Greek-Roman (polis) variant. Obviously, where the basis of economic life is the village, and the main social unit is the community (as among nomadic peoples), the process of state genesis proceeds in line with general laws, but in different ways than in the Greek-Roman world.

The change of the clan organization of the social management to the political one, the state, is not an instantaneous but a gradual, lengthy process, full of contradictions and drama.

The division of the population into administrative-territorial units and the distribution of state power according to the territorial principle means not only the emergence of a state organization but also the beginning of the process of formation of individual countries. The territory, which most important parameters, in turn, are determined by geography and location, is of no small importance for the historical destinies and prospects of any state or people. Moreover, in the ancient period of the history of mankind, when nature continued to dictate to people the forms of life order and economic organization, the geographical factor played a decisive role in the life of people and states.

We should take into account that geography and location have many aspects, such as the size and scale of the 
territory of a particular state, its location, topography, climate, conditions for agriculture, the availability of natural resources, access to seas and oceans, etc. These aspects determine the number of parameters that indicate the potential and real capabilities of the state, determining its place among other states.

As historical experience shows, the land itself, the territory of the state constitutes that strategic resource, which possibly surpasses all other resources in its importance.

According to L. Duguit, "the character of the state can and should be given credit only for collectivity, which has political power and lives in a certain territory" [Dugi, 1908.]. Therefore, it is not surprising that the very concept of political power was identified from the very beginning with the administration of power in a certain territory and with this territory itself.

The second feature of the state is associated with the establishment of a special public authority, which does not directly coincide with the interests of the population [Baitin , 1972]. The tribal community had tribal potestary power (from lat. potestas - strength, power), the essence of which is cruel coercion. It extended only to relatives and was carried out on the basis of a kinship; only members of the clan obeyed it because of their personal dependence on the collective. The public power is distributed according to the territorial principle; it subordinates everyone staying in a certain subject territory. These "all" represent dependent people, population, "public", a set of abstract objects of power (subjects or citizens). For the public authorities, it does not matter whether they are bound by kinship or national ties or not. The public authority on its territory is subordinate to all citizens. Any power, including state power, is a special function in guiding, managing, and coordinating the volitional actions of people. State power, manifesting in such people, is not reduced only to the above [Valentin 2018]. It means something more. State power leads to the establishment of relations it acts in as the highest authority, voluntarily or involuntarily recognized by all members of the social community that has developed in this territory. Powerful leadership presupposes, on the one hand, the ability of carriers of power functions to determine the behavior of people, and on the other hand, the need for those subject to subordinate their behavior to power command. Submission is the result of both persuasion and coercion. Power is, above all, a force able to subordinate. The loss of this quality paralyzes power with all the ensuing consequences [Liubashits, et al 2018].

Different attitudes cause different reasons for the subordination of the subject to state will. Such subordination may be the result of the use of direct coercion or the threat of its use; remuneration or expectation of remuneration for submission to the state will; adaptation of goals subject to the state will; or identification of their goals with the state will; finally habits. All these factors, of course, are actually combined and intertwined with each other, acting as a system of social motives for obeying the will of the state. However, this in no way excludes the possibility that any of the listed factors in a particular situation becomes a priority.

Power is an integral property of the human community. As a social phenomenon, it appears as a perfect and objective regulator of social relations. Being generated by such relations, power, in turn, acts as a tool for organizing society, establishing discipline and order [Liubashits 2002; et al 2013].

Joint activity in any society is due to the fact that people never lived in isolation from each other; communication is a necessary condition for the existence of people. Therefore, the genesis of power should be sought in the very necessity of the human community. Such a hostel contributes to a psychological need for subordinating an individual to a single social will, a feeling of dependence, a state of subservience on one side and a feeling of lust for power, and a will for power on the other.

Of course, the phenomenon of power is not only a psychological phenomenon; it arises under the influence of the social conditions of life as a public function to guide the labor process. In its most general form, power is considered as a function of any organized group of people to establish their joint activities using special methods (persuasion or coercion) to achieve certain goals. This is the perception of power as a social function that was still inherent in primitive society: the social power of a tribe, phratry, clan, exercised by the councils of elders of clans and tribes, by popular assemblies (such as the ancient Greek agora), etc. Such power is not separated from its source and carrier, expresses the general interests and needs of society, and is used to guide its general affairs.

Thus, a special social function of power should be noted as its main feature (in the social sense of the word). It is a functional approach that makes it possible to distinguish the most general concept of power from its other, particular manifestations that characterize certain forms of power activity (power as a relationship of domination and subordination, power relations, etc.). This approach ensures the separation of power into a relatively independent sphere, different from other types of social activities. Within the framework of this sphere, a collective bearer of power is formed - a stable, organizationally ordered social structure represented by some unit of society (family, social organization, etc.), and finally, the people as a universal community of people. 
As the state arose, power alienates from society and becomes a hallmark of any state, acquiring a political character. This means that power, as a social function, is transformed into political power.

There are various approaches to understanding its nature. Some modern authors (R. Dahl, P. Calvert, and others) believe that it precedes the state and exists in any group - a trade union, club, tribe, company, etc. Marxist theory links political power to the emergence of classes and the state. There are other views, however, political power is usually associated with the struggle of social groups for the distribution of social values in a socially asymmetric society (politics as a way of redistributing social statuses in society).

Since the people who form the special apparatus of political power, government, and the court do not directly participate in the production of material goods, they need material means for their maintenance. These funds are collected from the population in the form of taxes and loans, which is the third feature of the state organization of the society.

Ancient society did not know this institution, since it did not have a control apparatus and direct coercion, which, without participating in the production process, became a "dependent" in society. Privileges of officials are a means of ensuring their behavior and activities in the interests of economically dominant social groups.

Taxes, therefore, were not always the main source of replenishment of the treasury. Taxes are usually understood as obligatory payments established and collected by the state from its citizens.

We should say a few more words about law as a special regulator of social relations. An important fourth feature of the state is the expression of the will of the ruling class, social groups in the rule of law and, thus, giving this will a universally binding character [Baitin,2001].

The preceding system knew neither what law and duty are in the legal sense of the word, nor even division into rights and obligations in general.

At a very early stage of social development, the need arose to embrace the general rule of routinely repeated acts of production, distribution, and exchange, and to make sure that the individual complies with the general basic requirements of public life. These rules, initially expressed in a custom, gradually turned into the law. Legal customs and laws gradually evolved into a system of law. Compliance with the rule of law is ensured, if necessary, by state coercion.

Since ancient times, from the very first monuments of law - laws, charters, collections of legal customs and court decisions, other legal documents - through a series of contradictory elements, when the legal scope is sometimes torn by class interests, political passions, or even self-will, arbitrariness of the ruler-lawmaker, it invariably shows the primordial (which finds expression in the very fact of introducing and maintaining generally binding norms, legal procedures, decisions that are the same for the entire population) - the aim to establish a single, stable, suitable order of human behavior, a reasonable resolution of conflicts, taking into account the interests of various persons, these participants relations, and security of their rights.

\section{Summary}

The traditional state can be characterized as a specific form of a political organization since it contains all the institutions that ensure the management of the whole society and its preservation; there is also a monopoly on the legitimate use of force and the use of higher sanctions that exclude any appeal. A society of early statehood is defined as a centralized institution already able to force the population to work and war (Carneiro) and having a monopoly on legitimate violence in the territory (Weber). The state is ready to perform key functions related to the organization of military force in maintaining the legitimacy of the social order. At the same time, the specifics of the traditional state as a historical type manifested in its systemic characteristics (functions, structure, and forms), which cannot be fully compared with the organizational features of states of other historical types, primarily the modern state. In order to better understand this specificity, the structure, functions, and forms of the traditional state should be considered using the vast, specifically historical material.

\section{References}

Apolskii, E., Baranov, P., Mamychev, A., Mordovtsev, A., \& Ovchinnikov, A. (2017). Doctrinal and legal developments of the state law institutions in the context of the Russian legal mentality (XIX- early XX centuries). Man in India, 97(23), 105-113.

Baburin, S. N. (1997). The territory of the state. Legal and geopolitical issues. M.

Baitin, M. I. (1972). State and political power. Publishing House of Saratov University.

Baitin, M. I. (2001). The essence of the law. Saratov. 
Berent, M. (2000). The Stateless Polis: the Early State in the Ancient Greek Community. Alternatives of Social Evolution. Vladivostok.

Butenko, A. P. (1993). State: its yesterday's and today's interpretations. State and Law, (7), 13-19.

Claessen, H J. M., \& Skalnik, P. (Eds.). (1978). The Early State. The Hague: Mouton. https://doi.org/10.1515/9783110813326

Dugi, L. (1908). Constitutional law. The total territory of the state. M.

Fried, M. (1967). The Evolution of Political Society: an essay in political anhtripology. N.Y.: Columbia University Press.

Ghazanfarpour, H., Pourkhosravani, M., \& Mousavi, S. E. (2013). Geomorphic systems affecting the Kerman. UCT Journal of Social Sciences and Humanities Research, 1(1), 6-11.

Grafskii, V. G. (2003). General history of the state and law of foreign countries. V. 1. The ancient world and the Middle Ages. Moscow; Stavropol.

Kradin, N. N. (2001). Political anthropology. M.

Liubashits, V. Ia. (2002). State and society: the experience of system analysis. North Caucasian Legal Bulletin, (3).

Liubashits, V. Ia. (2002). State power: concept, features, and types. Jurisprudence, (6).

Liubashits, V. Ia. Mordovtsev, A. Iu., \& Mamychev, A. Iu. (2015). Theory of State and Law. RIOR: INFRA-M.

Liubashits, V. Y., Shirshov, A. A., Lopukhinskii, L. M., Khizbullin, F. F., \& Stratonova, L. M. (2016). Psychological bases of formation of key economic information technology specialist competencies of higher education. International Review of Management and Marketing, 6(6), 114-118.

Liubashits, V., Razuvaev, N., Mamychev, A., \& Shestopal, S. (2018). Signs of State and Their Historical Modifications. Journal of History Culture and Art Research, 7(3), 175-186. https://dx.doi.org/10.7596/taksad.v7i3.1746

Lyubashits, V. Ya., Razuvaev, N. V., Mamychev, A. Yu., Mordovtsev, A. Yu., \& Magomedov, R. M. (2018). State as Evolving Phenomenon: Key Problems and Approaches. Amazonia Investiga, 7(15), 32- 41.

Mamut, L. S. (1996). State: poles of representations. Social sciences and the present time, (4).

Vengerov, A. B. (1983). The value of archeology and ethnography for legal science. Soviet state and law, (3), 32.

Zakharov, A. (1992). Once again about the theory of formations. Social sciences and the present time, (2), 51.

\section{Copyrights}

Copyright for this article is retained by the author(s), with first publication rights granted to the journal.

This is an open-access article distributed under the terms and conditions of the Creative Commons Attribution license (http://creativecommons.org/licenses/by/4.0/). 